\title{
14. Causes and consequences of family dissolution in Europe and post-divorce families
}

\author{
Dimitri Mortelmans
}

\section{INTRODUCTION}

This chapter looks at the uncoupling of relationships, both married and cohabiting. Relationship dissolution, and specifically divorce, is a phenomenon that has attracted the attention of social scientists since the 1970s. However, the perception that the rate of union dissolution has increased dramatically over the last half-century is only partly true. The divorce rate has indeed increased, leading some scholars to declare the end of a period in which Western societies were governed by the motto that 'what God has joined together, let no one separate', or the assumption that marriage will last 'till death do us part'. But it is important to keep in mind that divorce has existed throughout human history, and is much older than the current Western tradition of marrying and divorcing. For example, the Babylonian Code of Hammurabi (1772 BCE) already contained legal regulations governing marriage and divorce (Trevino 2013). Nonetheless, the research we discuss in this chapter captures a previously unobserved decoupling trend. In recent decades, relationships have become less stable, and, as we will discuss, are increasingly intertwined with social inequality. We start this chapter by defining the central concepts of divorce and separation. We then outline the general trends in divorce in the industrialised world. Next, we explore the risk factors for divorce, and discuss some of the consequences a break-up is likely to have for the ex-partners and their children. While we employ a European perspective, we cannot ignore the large amount of empirical evidence on this topic from the United States (US). Where possible, we introduce the reader to comparative studies that place the divorce phenomenon in an international perspective.

\section{DEFINING DIVORCE AND SEPARATION}

Divorce is the central concept in this chapter, and is a term that seems almost unnecessary to define. Divorce is most commonly defined as the legal dissolution of a marriage. Rates of divorce are captured in official statistics, and can be compared across countries (see below). However, a divorce can also be seen as the end point of a more complex process during which the quality of a marriage deteriorates, as conflicts between the partners arise, and they become increasingly estranged. While sociologists and demographers often consider the break-up of a couple as a discrete phenomenon or life event, the end of a long-term relationship generally does not occur at a single moment in time.

The moment the partners are divorced, they receive the legal status of 'no longer being married'. But prior to that point in time (i.e., the divorce event), the partners had already been in a process of uncoupling. From the perspective of family law, there are two (potential) phases that couples go through. In the first phase, the partners decide to end their relationship. Often, 
one partner subsequently moves out of the marital home, which means that the two ex-partners are, from a legal perspective, (spatially) separated (but still married). In the next phase, the partners are legally separated (sometimes also known as 'divorce from table and bed'). In some countries, the partners can ask the court to take preliminary measures that apply until the divorce is finalised. In this period, the partners remain married, while a judge makes decisions regarding the rights and duties of the respective partners, such as their rights to property (e.g., who lives where), their obligations to pay ex-spousal alimony and child maintenance, and their rights to child visitation. In some countries (e.g., Italy and Germany), this period of legal separation represents an obligatory legal separation. The idea behind this obligatory separation is that the partners should have a 'waiting period' (or probationary period) before their divorce is finalised; i.e., that the partners may be ending their marriage prematurely, and would therefore benefit from a 'cooling down' period before they take the final step of dissolving their marriage. In practice, however, very few legally separated couples reconcile. Thus, most countries have abolished this obligatory separation period (Senaeve 2000).

The second phase is the divorce procedure itself. In this legal process, the partners officially request that the government dissolve their marriage, and award them the administrative status of 'divorced' (or in some cases 'unmarried'). While a divorce is usually granted through a court decision, it might also be finalised through an administrative procedure pursued by a municipal officer or a notary. As divorce laws differ significantly across countries, both the procedures used and the length of the divorce process can vary considerably.

In a highly diverse society, this legal approach to divorce hides the reality that the phenomenon of uncoupling takes many forms. When family researchers started studying the increase in divorce, their sole focus was on union dissolution among married heterosexual couples. But given that in many countries same-sex couples are now permitted to marry, these couples also face the risk of divorce. Furthermore, divorce researchers have been forced to expand their focus as rates of marriage and divorce have declined, and cohabitation and union dissolution have become more common. Thus, even though we still use the term divorce, it no longer refers exclusively to the decoupling of married, heterosexual spouses. Rather, it has become an umbrella term for all uncoupling processes, irrespective of the gender composition or the legal bond of the couple.

In addition to identifying who is experiencing a break-up, we need to consider the life course perspective on coupling and uncoupling. When discussing divorce, the impression could arise that most people have one long-term married or cohabiting relationship that might be dissolved at some point during the life course. In reality, life - but also the heart - goes on after divorce. Re-partnering is inherent in the pattern of the formation and dissolution of partnerships. When a new partner enters the life course of an individual, $\mathrm{s} /$ he opens her/himself up not only to a new love, but to new potential conflicts that could result in a higher-order break-up (and, hence, in new partnerships). As divorce is often regarded as an event that each person experiences only once, these subsequent processes of bonding and relationship dissolution are not well understood. At present, divorce research is predominantly focused on divorces of first marriages, even though the process of finding a partner and then leaving a partner could occur numerous times over a person's entire life course (Amato 2010). 


\section{FAMILY LAW AND UNCOUPLING}

When reviewing the evolution of divorce laws, we first need to look at the concept of marriage. In Europe and the US, marriage has long been a patriarchal institution in which a wife was more or less the property of her husband. In his classic study on the 'leisure class', Veblen (1965) described how wealthy men use their spouses as signifiers of their wealth by adorning them with jewellery and expensive clothes. For centuries, men were given complete control over women's property, earnings, and sexuality. Moreover, in choosing a marriage partner, whether the union enhanced the political power or property of the respective families was considered more important than the level of love and intimacy between the partners (Coontz 2006). ${ }^{1}$ Thus, in many countries, divorce was either prohibited or allowed only under very strict conditions. In addition, as filing for divorce was very expensive, only the rich had access to divorce, while poor people often split up without officially divorcing. The shift from arranged marriage to modern marriage, in which the main focus is on personal fulfilment and emotional attachment, also instigated a shift in thinking about marriage dissolution. The modernisation of 'the love match' (Coontz 2007) not only revolutionised marriage, it set in motion a trend towards divorce, as the focus on individual fulfilment and mutual love in marriage also implied that loveless relationships should be ended. As long as divorce was forbidden, it remained in the shadows, with couples splitting up but never publicly moving on to a new relationship or a new marriage. This shift in the perception of marriage inspired family law regimes to provide new options for legally ending a marriage.

Until the late 1950s and 1960s, divorce in Europe and the US was prohibited except in well-specified cases. The only grounds for leaving a marriage were adultery, violence, or (large) debts. A first step in the loosening of divorce laws was the introduction of mutual consent regimes and fault divorces. In such cases, divorce was allowed only when both partners consented (unless the aforementioned grounds for divorce were present) or when a guilty party could be identified. As in criminal law, the family judge who dissolved a marriage named a guilty and an innocent party. How property was divided and which partner got custody of the children often depended on which partner won or lost the divorce case. From the 1970s onwards, divorce law underwent two additional changes (although these changes did not occur in every state and country, and the pace and the degree of these changes varied). The first major change was the introduction of the no-fault divorce, in which the end of a marriage was no longer legally attributed to the 'fault' of one partner. In some jurisdictions, the classic divorce grounds were retained, and a no-fault divorce was offered only as an alternative to seeking a divorce based on wrongdoing. In other jurisdictions, all divorces were considered no-fault divorces, and proof of guilt was abandoned as a legal principle. Parallel to the introduction of no-fault divorce, unilateral divorce became a legal option. Under traditional divorce law, couples need to provide mutual consent to divorce. If one partner wanted to stay married, divorce was not possible (or had serious consequences in terms of property rights and child custody). With the introduction of unilateral divorce, if one partner decided to divorce, the law no longer forced that partner to stay married, even if the other partner refused to consent to the divorce. As we mentioned above, these changes in divorce law were also accompanied with a streamlining of legal procedures. Waiting periods were abolished in many countries, and the total length of the divorce process was reduced. An overview of legalisation of divorce and the shift towards no-fault and unilateral divorce can be found in González and Viitanen (2009). 
Several studies that have examined the question of whether these 'easier' legal options for obtaining a divorce have influenced overall divorce rates (see the next section). They have found that changes in divorce laws caused sudden spikes in the overall trend in divorce rates that dissipated over time. Wolfers (2006) showed for the US and González and Viitanen (2009) found for Europe that the shift towards no-fault and unilateral divorce legal regimes has caused overall divorce rates to increase by between 0.2 to 0.4 divorces per 1000 people per year. While the option of unilateral divorce contributed to this trend, it was the introduction of the no-fault divorce option that had a significant (albeit limited) surplus impact on the divorce rate.

It is important to stress that improved access to divorce and the expansion of legal options for obtaining a divorce through the evolution of family law are not the only changes that have affected trends in marriage dissolution. Parallel to this evolution, child custody arrangements in divorce settlements have received increasing attention. The first divorce laws mostly focused on the material well-being and living arrangements of the couple's children. As it was assumed that the welfare of children was best served by living with their mother (except in cases of abuse or neglect), mothers were automatically granted child custody, while fathers were automatically required to pay child maintenance. Although laws regarding financial obligations following divorce differ between countries, the general principle is that financial compensation is given to the financially weakest party, and to the party most involved in raising the children (Claessens and Mortelmans 2018). However, as the cultural understanding of marriage has evolved, views on parenting, and on fathering in particular, have changed. In response to the growing expectation that fathers contribute to the socialisation of their children, joint legal custody has been introduced, followed by joint physical custody (Nielsen 2018; Steinbach 2019). In addition to regulating living arrangements, family law regimes are increasingly reminding parents that they have lifelong parenting responsibilities, even after their partnership ends. In the Netherlands, for example, couples are obliged to draw up a 'Parenting Plan', which is a binding agreement that outlines how the parents plan to provide care and support for their child, and how they intend to communicate and inform each other about the child's well-being (de Bruijn et al. 2018).

\section{DIVORCE TRENDS}

It is well known that divorce occurs across the globe, and that divorce rates have been rising until very recently (Emery 2013). For decades, statistical offices have monitored marriage and divorce trends based on several indicators. In all countries, there is evidence that rates of relationship dissolution have been rising. The most simple indicator that can be used to track divorce trends is the absolute number of divorcees. For a given population, we can count the number of people who are currently divorced (and not remarried), and can follow that number over time. The advantage of basing an analysis on the absolute number is that it reflects the current size of the group of divorcees. The disadvantage of doing so is that the proportion of divorcees could stay stable when the population itself is growing. Therefore, the crude divorce rate is used more frequently in time series. This measure is defined as 'the ratio of the number of divorces during the year to the average population in that year. The value is expressed per 1000 inhabitants' (Eurostat 2019). Table 14.1 gives an overview of the crude divorce rate for selected countries since 1960 . 
Table 14.1 Crude divorce rate (1960-2010) in five selected countries

\begin{tabular}{lllll}
\hline & $\mathbf{1 9 6 0}$ & $\mathbf{1 9 8 0}$ & $\mathbf{2 0 0 0}$ & $\mathbf{2 0 1 0}$ \\
\hline France & & & 1.9 & 2.1 \\
Germany & 1.0 & 1.8 & 2.4 & 2.3 \\
Sweden & 1.2 & 2.4 & 2.4 & 2.5 \\
United Kingdom & & 2.6 & 2.6 & 2.1 \\
United States & 2.2 & 3.5 & 4.0 & 3.6 \\
\hline
\end{tabular}

Source: National Center for Health Statistics (2019); Eurostat (2019)

The disadvantage of relying on the crude divorce rate is that it does not take into account the composition of the population. For example, if the birth rate is decreasing, the divorce rate will rise automatically (even when the number of divorces stays stable). The divorce rate also increases when the age at marriage decreases, as couples have a higher risk of divorce at younger ages. Therefore, the refined divorce rate can be used to calculate the number of divorces in a given year relative to the number of married women in a certain age bracket.

For decades, demographers, economists, and family sociologists have been debating trends in divorce, particularly in the US. These analyses have generally taken two different effects into account: period and (marriage) cohort effects. Period effects occur when all marriages are influenced by a phenomenon at the same time. An example of a period effect is a change in divorce law. Cohort effects (we are referring here to marriage cohorts, and not to birth cohorts, as is often done in demography) occur when couples marrying in a specific year do so under different conditions than cohorts marrying in another year. An example of a cohort effect is a change in attitudes or values that affects a certain marriage cohort. If members of a younger marriage cohort no longer see marriage as a lifelong commitment, but as a contract that could be broken, this cohort might have different divorce risks than older cohorts. Most of these studies concluded that period effects in divorce are larger than cohort effects (Teachman 2002).

The results displayed in Table 14.1 show that crude divorce rates have been rising for decades. Explaining this sharp increase is difficult. Both economic and cultural theoretical models have been developed to explain why divorce rates have been increasing in the industrialised world. The economic theory of the family sees specialisation and mutual dependence in couples as protective factors in relationships. The sex-specific specialisation in the male breadwinner model led to the development of a family system that was supposed to optimise marital resources and human capital (Becker 1981). It thus appeared that the increase in the number of women entering the labour market since the 1970s disturbed this equilibrium, and gave rise to more break-ups. Indeed, there is empirical evidence of a correlation between female employment and divorce trends in many countries (Kalmijn 2007). This cultural explanation is known as the theory of the second demographic transition (Lesthaeghe 2010). According to this theory, the demographic changes that have been taking place since the 1960s (including the increase in divorce) have been driven by individualisation, secularisation, and a rise in post-materialist values. These changes have led to a deinstitutionalisation of marriage (a weakening of the power of social norms to dictate the partners' behaviour) and, in turn, a lowering of the threshold for leaving a marriage (Cherlin 2004). This theoretical approach is more difficult to test empirically, as appropriate and constant measurements of values are often lacking in longitudinal household surveys (and are entirely absent in administrative data). Nevertheless, some efforts have been made to examine the validity of this theory by looking at 
gender-egalitarian values in couples (e.g., Kaufman 2000). The results of these studies indicate that men with more egalitarian attitudes have a lower risk of divorce.

More recently, a levelling off of or even a decline in divorce has been observed in some countries. This evolution in crude divorce rates has led to the formulation of new research questions regarding macro-level developments. The first and most important question that arises is: 'Have marriages indeed become more stable?' As a decrease in divorce rates suggests that fewer people are divorcing, it may be assumed that marriages have become more stable. However, a second, related question then presents itself: 'Given that unmarried cohabitation is becoming increasingly common, is it possible that the plateauing of divorce rates is attributable to the rise in unmarried cohabitation?' After all, these couples do not enter marital or divorce statistics. With respect to the first question, the outcomes of earlier advanced statistical analyses showed that there was no real decrease in divorce rates (Goldstein 1999). However, more recent analyses have found that although divorce rates decreased between 1980 and 2000, more recent marriage cohorts are more stable, as the divorce risk has fallen among younger couples (Cohen 2018). A partial explanation for this recent decline in divorce risk is the selectivity of marriage: i.e., that those who choose to marry in a time when unmarried cohabitation is becoming the norm are in more stable marriages. Research on cohabitational break-ups has shown that unmarried cohabitation is less stable than marriage (Guzzo 2014). The explanation for this effect lies in the selection into these types of relationships. The value patterns of cohabiting couples are more individualised, and are therefore less stable. Liefbroer and Dourleijn (2006) have also shown that the prevalence of cohabitation in a country reinforces this effect. Thus, while it is possible that the increase in unmarried cohabitation is responsible for the levelling off of divorce rates, this issue has yet to be conclusively settled.

\section{DIVORCE RISKS}

By defining the concept of divorce and discussing the national trends in divorce, we have demonstrated the complexities that we must take into account before we start studying the phenomenon of divorce. These intricacies only multiply when we move past the process of the event itself. The field of divorce studies is divided into three domains: namely, the causes, the processes, and the consequences of divorce. These domains have not been developed to the same degree. For example, as we have little in-depth knowledge about the process of divorce, we are unable to include it in this chapter. We do, however, have considerable knowledge about the antecedents and the consequences of divorce. Nevertheless, providing a concise overview of all of the causes and consequences of divorce is an impossible task for a chapter in a textbook. Some excellent overviews are available, and the interested reader will find much more detail there than we are able to provide here (Bradbury et al. 2000; Lyngstad and Jalovaara 2010). We deliberately chose the term 'divorce risks' as the title of this section. Although we often refer to the causes or antecedents of divorce, it is important to keep in mind that relationship instability can never be perfectly predicted. While research has shown that certain couples have an elevated risk of divorce, such results do not tell us whether their relationships will actually end. Moreover, the phenomenon of divorce is so multifaceted that not a single marriage would survive if divorce risks were deterministic.

No general theory has been proposed that is capable of explaining the multiple pathways into divorce. Nevertheless, some scholars have tried to develop a general theoretical frame- 
work. The most prominent general theory is the social exchange theory of Levinger (1965, 1976). Levinger based his theory on the observation that the bond of marriage can be explained by the cohesiveness of a social group. In other words, if we want to know why partners stay together, we have to look at why members of a group stay together as a group. The marital bond is kept together by three forces: (1) the attractiveness of the marriage itself, (2) the costs of breaking up, and (3) the inverse relation between the attractiveness of the marriage and cost of the alternative (being single or entering another relationship). The attractiveness component consists of affectional (love, charm), material (income, assets), and symbolic (status) rewards. The costs of leaving the relationship are also affectional (risk of loneliness), material (risk of becoming poor), and symbolic (risk of stigma as divorcee). The third component in the theory shows that the relationship is based on a constant evaluative balance. Partners exchange benefits and costs, and evaluate whether their balance is (still) greater than potential alternatives. This subjective cost-benefit ratio is usually referred to as 'marital quality', and is measured using indicators of marital satisfaction. Levinger's theory has inspired divorce research from both the macro (e.g., Wagner 2019) and the micro perspective (e.g., Boertien and Härkönen 2018). The risk factors we discuss in this section can all be classified as benefits, costs, or alternative attractions. However, these risk factors can also be characterised as psychological, sociological, economic, and biological risk factors. Some of these risk factors were mentioned earlier in this chapter. For example, we have noted that premarital cohabitation or unmarried cohabitation is associated with an increased risk of divorce (Guzzo 2014; Rosenfeld and Roesler 2019).

Levinger's theory identified marital satisfaction as an important risk factor in divorce, and this factor has been extensively examined in psychological studies on divorce. Marital quality studies have focused on the interpersonal processes between partners, and, more specifically, on how partners deal with conflict and solve problems. Both visible (violence) and invisible (emotions, interpretations of behaviour) (re)actions are taken into account (for an overview, see Bradbury et al. 2000). In addition to marital satisfaction, personality has been shown to influence the stability of a relationship, with some personality traits outperforming socio-economic risk factors in predicting divorce (Roberts et al. 2007). We can expect personality to become an even more important risk factor in the future as the erosion of traditional family norms progresses (and external barriers to divorce weaken). Personality is often studied with the aid of the 'Big Five' model, which refers to five traits that make up an individual's personality, and that influence his/her relationship stability to varying degrees. Neuroticism, extraversion, and openness are linked to an increased risk of relationship dissolution; whereas conscientiousness and agreeableness are associated with a reduced risk of relationship dissolution (e.g., Lundberg 2012). People with high levels of agreeableness and conscientiousness tend to have stable marriages (e.g., Boertien and Mortelmans 2017), while people who are highly neurotic (difficult to live with) or highly extraverted (constantly open to new alternatives) are more likely to divorce.

From a sociological or demographical perspective, both timing factors and individual characteristics are risk factors for divorce. Among these timing effects is the intergenerational transmission of divorce. Having divorced parents increases the risk of divorce; thus, children of divorced parents are more likely to divorce themselves. The explanations given for this phenomenon are threefold. First, children of divorced parents might lack relationship skills, as they are less likely to learn these skills while being socialised. Second, children in broken families may 'learn' from their parental home that a marriage is something that can be broken 
(Amato and DeBoer 2001). Third, the stress of the divorce and a decline in financial resources (see the consequences of divorce) may lead children of divorced parents to leave the parental home early, and to enter a partnership at a younger age than their peers. As this can result in a less optimal partner match, their risk of divorce increases. This last explanation is also used in a more general way to account for the effect of age at marriage: the younger a person is when $\mathrm{s} /$ he marries, the higher his/her divorce risk is (South 1995). Another life course-related risk factor is the rank of the marriage. Higher-order marriages are less stable than first marriages, as there appears to be no learning effect of a first divorce in terms of marital stability. Rather, there is evidence that having undergone a divorce lowers the threshold for separating a second or third time (Coleman et al. 2000). As divorcees often enter cohabitating relationships after the break-up, the lower level of stability in higher-order relationships is also partly explained by the type of relationship. As we noted previously, studies have shown that cohabitating relationships are less stable than marriages (Guzzo 2014; Wu 1995). This pattern is partly attributable to a selection effect (or a weeding effect), as the strongest cohabitations often turn into marriages, which, in turn, increases the dissolution risk of cohabitations as a whole. Other explanations for this higher dissolution risk are that cohabitation is considered a trial marriage (cohabiters are less certain of their partner choice, and may indeed conclude that a match is not suitable), and that people who cohabit have different value patterns than people who marry (Liefbroer and Dourleijn 2006). As we mentioned above, the second demographic transition theory posits that changes in values have resulted in demographic changes. For example, having more individualised values and being less religious tend to increase the risk of divorce (Lehrer and Chiswick 1993).

Two sociological risk factors for divorce that have attracted considerable attention in the literature are related to the partners' educational attainment levels and their children. The question of whether having higher educational attainment increases or decreases the risk of divorce has sparked huge debates in the literature. Most of the studies that examined this topic focused on the effect of female education. According to classic economic theories of the family, women with higher education (i.e., more human capital) have more opportunities to leave the marriage, which destabilises the relationship, and thus increases the risk of divorce (Becker 1981). However, it has also been argued that women with higher educational levels tend to have higher levels of economic security, which can reduce the financial stress in a relationship, and help to stabilise the marriage (Oppenheimer 1997). The results of a recent meta-analysis suggest that these mixed findings are attributable to a reversal of the educational gradient over time (Matysiak et al. 2014). Cross-country analyses (Härkönen and Dronkers 2006) uncovered evidence not only of a change in the gradient, but of huge international differences in the effect. The number of studies on the protective character of children is far smaller. Having children is a protective factor that reduces the risk of divorce among both married and cohabiting couples (Steele et al. 2006). Children are a 'marriage-specific capital' (Becker et al. 1977, p. 1154), which means that the 'costs' of dissolving the marriage are higher, both economically and emotionally, when children are involved. It is, however, worth noting that the ages of the children matter: i.e., that the protective effect of children diminishes as they grow older (Waite and Lillard 1991).

The economic risk factors of divorce are generally related to income and labour force participation. The focus of the literature on these factors has been on the so-called specialisation and independence hypotheses. According to the Beckerian specialisation theory (see above), when gender specialisation in the marriage is disrupted by female employment, the risk of 
divorce goes up. While some authors have found evidence for this specialisation hypothesis (e.g., Jalovaara 2001), the independence hypothesis has been widely criticised, and countered with the argument that a marriage tends to be more stable when both spouses contribute to the income of the household (Oppenheimer 1997). In addition, the effect of the wife's employment on the couple's divorce risk differs depending on whether the partners are living in a country with social policies that support (gender) equality, and that encourage a more equitable division of unpaid household labour (Cooke et al. 2013). The global economic crisis of 2008 has also revived interest in the association between unemployment and divorce. Especially for men, unemployment has a negative impact on relationship stability (Charles and Stephens 2001; Solaz et al. 2020). However, in difficult economic times, there is a negative relationship between the unemployment rate and the divorce rate (at the country level) due to the postponement of divorce (Amato and Beattie 2011).

Finally, it should be emphasised that many other risks in addition to those discussed above have been identified. When either of the spouses or their children have health problems (physical or mental), the risk of divorce increases. Domestic violence and alcohol or drug abuse are also positively associated with instability. Furthermore, genetic research has been looking into the genetic components of the intergenerational transmission of divorce (D'Onofrio et al. 2007). A very recent domain of investigation has even been examining the role of technology - and, more specifically, of social media use - in relationship break-ups (Clayton 2014).

\section{CONSEQUENCES OF DIVORCE}

In their 1991 meta-analysis, Amato and Keith (1991) identified eight domains of the consequences of divorce for children, which were additionally mediated by several socio-demographic background characteristics. For adults, the consequences of divorce have been studied in the domains of psychological adjustment (well-being); health (physical and mental); social adjustment (social networks and loneliness); economics (income and poverty); behavioural adjustment (drinking, drug use, violence); parenthood (both from the child's and the parent's perspective); and, in particular, children's custody arrangements (both legal and physical) and educational attainment. These consequences have been studied in both the short and the long run. Amato and Cheadle (2005), for example, have looked at the consequences across three generations, and found significant negative effects of (grand)parental divorce on children's educational attainment, marital quality, and levels of contact with their own parents. The consequences also have been studied from both a cross-sectional and a longitudinal perspective. The use of such approaches is important, given that research on the consequences of divorce has to address the selection-causation question. Partners who divorce are confronted with consequences that might have been already present during the marriage. Thus, these consequences may have played a role in the deterioration of marital quality that eventually led to the break-up. As we will discuss in more detail below, the ex-partners might suffer financially after a divorce. Moreover, as we pointed out above, financial stress and economic hardship can lead to marital problems, and, eventually, to the dissolution of a marriage. Therefore, when evaluating studies on the consequences of divorce, we need to consider both the time since the divorce (as some consequences wane after a period of time) and selection issues (as these factors might significantly reduce the severity of the consequences). 
As our discussion up to this point makes clear, the potential consequences of divorce are so extensive that even a separate chapter on this topic would struggle to provide an overview of all of the existing research results. Therefore, we refer the reader to some overview studies, as we did above in our discussion of the causes of divorce (Amato 2000, 2014; Amato and James 2010; Kelly and Emery 2003; Wallerstein 1991). In the remainder of this section, we will focus on two specific consequences: one for adults and one for children. First, we will examine the economic consequences of divorce for ex-partners. As a decline in income is associated with many other aspects of people's well-being, including their health, we think that this domain is an important field of study. In our examination of the consequences for children, we will focus on the educational attainment of children whose parents divorce. As educational attainment greatly influences the subsequent life course of an individual, it is an important domain that has been extensively studied.

When we look at research on the financial consequences of relationship dissolution, we see that one central finding dominates: namely, that in financial terms, women suffer more from a break-up than men. DiPrete and McManus (2000) reported for the US that, on average, men lost 15 per cent of their adjusted household income, while women lost 26 per cent of their income following a divorce. This finding is surprisingly constant over time. For example, Hauser et al. (2016) reported that US women experienced a decline in income of 25 per cent; while de Vaus et al. (2017) found a decrease in income of 30 per cent. The results for Europe are comparable to those in the US, with women losing financially and men showing a more diverse pattern of gains and losses - even though the sizes of the changes in income are found to differ across European countries. These differential trends have been attributed to cross-country differences in labour market conditions, child-care infrastructure, and family policies (e.g., marital taxation systems, or financial subsidies for parental child care) (Andreß et al. 2006).

In addition to estimating the changes in income, researchers have looked at the strategies ex-partners develop to cope with their financial losses. When considering financial behaviour after a divorce, the literature tends to focus on two main coping mechanisms: finding a new partner, and changing one's labour market behaviour. Some studies have taken into account a third strategy: namely, returning to the parental home, which has also been called the 'boomerang effect' (Albertini et al. 2018). Studies that take re-partnering into account as a coping strategy have observed different effects based on gender, with men, on average, re-partnering more quickly and more frequently than women (Coleman et al. 2000; South 1991). One explanation for this pattern is that having (young) children will intensify a divorcee's economic needs, while at the same time lowering his/her chances of re-partnering due to his/her decreased meeting opportunities and level of attractiveness. A second explanation looks at a divorcee's job, observing that having a good job tends to increase a person's attractiveness, while also increasing the individual's re-partnering opportunities through intensified contacts and an enlarged network. From a Beckerian point of view (see above), this latter explanation only applies to men. For women, being employed will reduce their re-partnering needs (financially speaking), and make them less attractive, as they are less available to take on the female role in a specialised household with a single earner. Furthermore, socio-economic factors influence the re-partnering of both men and women, albeit in opposite directions. For women, a non-significant or a negative educational gradient has often been found. This has been characterised as an independence effect among higher-educated women (Ozawo and Yoon 2002). For men, their chances of re-partnering has been shown to increase as their educational level 
rises. The second strategy for coping with financial losses after divorce is to increase one's labour market participation. Increasing employment activities as a response to the breakdown of a relationship can improve a divorcee's income position, and lowers his/her risk of poverty (Dewilde 2006). Not surprisingly, women find it more difficult than men to increase their labour market participation, as their care burden often hinders or prevents them from working more. Moreover, pre-separation role patterns - with women tending to care for children at the expense of their careers - can influence a potential return to the labour market later on. These two strategies of re-partnering and increasing one's labour market participation are related. Research has shown that when these strategies are combined, seeking or remaining in full-time employment outweighs the benefits of re-partnering for women (Jansen et al. 2009).

The research has also repeatedly shown that children whose parents divorced have lower levels of educational attainment than children whose parents remained married. This observation is sometimes combined with the finding that less educated couples are more likely to divorce, which implies that their children carry a double burden. In response to these findings, McLanahan (2004) has developed the 'diverging destinies hypothesis', which states that the disadvantages people experience in childhood accumulate across their life course. In 1991, Amato and Keith (1991) performed a meta-analysis showing the (long-term) negative outcomes of parental divorce on children's educational careers. The effect size was found to be negative and significant. While differences were detected between boys and girls, these differences turned out to be non-significant. Follow-up studies conducted in the US provided mixed results, either confirming or contradicting these findings. Björklund et al. (2006), for example, initially observed a negative effect, but reported that this correlation disappeared after siblings-difference models were applied. However, scholars have been advised to proceed 'with caution' in interpreting these results (Sigle-Rushton et al. 2014), as the statistical technique used may have influenced the findings.

Having presented evidence that a parental break-up negatively affects children's academic achievement, we now look at why this is the case. Bernardi and Radl (2014) have proposed five mechanisms that could explain this negative correlation: (1) economic hardship after divorce, (2) changes in parenting, (3) increased parental stress, (4) the child's emotional crisis, and (5) selection. The socio-economic circumstances in the parental home are considered to be an indicator of the social context in which the child is growing up. As the family's financial circumstances become more difficult after divorce (see above), the child's opportunities are reduced, which can, in turn, lead to worse educational outcomes. However, Sigle-Rushton et al. (2014) pointed out that this correlation is subject to timing effects, and that the divorce is less likely to have a negative influence on the child's educational outcomes if $s /$ he is close to graduation. The second and third mechanisms attribute worse educational outcomes in children to changes in parenting processes and parental stress. A divorce is a stressful event (Amato 2000) that affects the lives of both children and their parents. As their parents are breaking up, the children tend to live (for a certain period of time) in a stressful environment in which they are receiving less parental attention. As a consequence, children may receive less support, and their grades might deteriorate. A similar argument refers to the fourth mechanism, but from the child's perspective. Stress and psychological maladjustment in children can influence their schoolwork, and, ultimately, their final educational level. The issue of selection has been discussed above, and is a more general theoretical argument that underpins the field of research on the consequences of family processes. 
Most studies on the consequences of divorce have been conducted in the US, where data from several long-running panel studies are available (Wallerstein 1991). Nevertheless, studies in the United Kingdom and Germany (Bernardi and Boertien 2017), Sweden (Björklund et al. 2006), and Finland (Erola and Jalovaara 2016) have confirmed the US results for the European context. More recently, international comparisons have reported that the correlation between parental divorce and educational attainment differs across countries. For example, Bernardi and Radl (2014), found a negative effect of divorce on educational attainment in all of the 14 countries they studied. They attributed these country differences to selection processes in the educational system; i.e., that when educational tracks are selected earlier, the divorce penalty is much greater.

\section{SUMMARY AND CONCLUSIONS}

In this chapter, we have provided an overview of existing divorce research. This field is so extensive that we were forced to make hard choices about the studies we included; thus, some interesting findings were left out. We started the chapter by defining divorce - or, rather, uncoupling, as cohabitations also dissolve, and tend to do so at a faster pace than marriages. Next, we looked at family law and the evolution of divorce procedures over time. The availability of unilateral and no-fault divorce has now spread to all industrialised countries. However, the main driver of the spectacular increase in divorce is not the law, but a combination of economic and cultural factors that have significantly influenced family life over the past 50 years. In the second part of the chapter, we discussed the extensive research on the causes and consequences of divorce. The many studies on this topic that have been published over the decades clearly indicate that divorce is a multifaceted phenomenon. A wide range of risk factors endanger marital stability, with between one-half and two-thirds of marriages ending in a divorce. Many of the same factors appear to affect the consequences of divorce. There is evidence that divorce has negative effects on the relationship stability of both adults and children, and that some of these effects can be measured across generations.

What will the future bring? As Cherlin (2004) showed more than a decade ago, predicting trends in family life has become a complex endeavour. One trend certainly seems to prevail: marriage is no longer a universal 'till-death-do-us-part' arrangement. The life courses of most people living today will be characterised by multiple waves of coupling and uncoupling. Complexities in the family kaleidoscope (Mortelmans et al. 2016) are increasing, and call for the development of new theoretical perspectives (Sigle 2016). While families and stratification processes are becoming ever more intertwined, we do not yet fully understand the impact these family complexities are having on the life course. As divorce researchers, we are not (yet) equipped to deal with this hyper-complexity. Some initial progress has been made in studies on union dissolution among same-sex couples (Andersson et al. 2006), trans people (Dierckx et al. 2018), or living apart together relationships (Connidis et al. 2017). Nevertheless, even though we have access to large-scale survey infrastructure and administrative data, most of these data are on traditional family forms like marriages and cohabitations. In order to develop new theoretical insights into the causes and consequences of divorce, mixed-method studies that provide timely insights into new and complex family processes are needed. One specific blind spot that demands attention is the role of technology. As Tinder and other dating platforms become increasingly widespread, family sociologists know little about whether the use 
of this technology represents a risk factor for relationships or a helpful tool in dealing with complex families by reducing stress and poor relationship quality. At this moment, we have no clue whether we should swipe left or swipe right.

\section{NOTE}

1. See, for example, the Head and Master laws in the US.

\section{REFERENCES}

Albertini, M., M. Gähler, and J. Härkönen (2018), 'Moving back to "mamma”? Divorce, intergenerational coresidence, and latent family solidarity in Sweden', Population, Space and Place, 24 (6), 1-12. doi:10.1002/psp.2142.

Amato, P.R. (2000), 'The consequences of divorce for adults and children', Journal of Marriage and Family, 62 (4), 1269-87. doi:10.1111/j.1741-3737.2000.01269.x.

Amato, P.R. (2010), 'Research on divorce: Continuing trends and new developments', Journal of Marriage and Family, 72 (3), 650-66. doi:10.1111/j.1741-3737.2010.00723.x.

Amato, P.R. (2014), 'The consequences of divorce for adults and children: An update', Društvena istraživanja: časopis za opća društvena pitanja, 23 (1), 5-24. doi:10.5559/di.23.1.01.

Amato, P.R. and B. Beattie (2011), 'Does the unemployment rate affect the divorce rate? An analysis of state data 1960-2005', Social Science Research, 40 (3), 705-15. doi:10.1016/j.ssresearch.2010.12.012.

Amato, P.R. and J. Cheadle (2005), 'The long reach of divorce: Divorce and child well-being across three generations', Journal of Marriage and Family, 67 (1), 191-206. doi:10.1111/j.0022-2445.2005 $.00014 . x$.

Amato, P.R. and D.D. DeBoer (2001), 'The transmission of marital instability across generations: Relationship skills or commitment to marriage?', Journal of Marriage and Family, 63 (4), 1038-51. doi:10.1111/j.1741-3737.2001.01038.x.

Amato, P.R. and S. James (2010), 'Divorce in Europe and the United States: Commonalities and differences across nations', Family Science, 1 (1), 2-13. doi:10.1080/19424620903381583.

Amato, P.R. and B. Keith (1991), 'Parental divorce and the well-being of children: A meta-analysis', Psychological Bulletin, 110 (1), 26-36. doi:10.1037/0033-2909.110.1.26.

Andersson, G., T. Noack, A. Seierstad, and H. Weedon-Fekjær (2006), 'The demographics of same-sex marriages in Norway and Sweden', Demography, 43 (1), 79-98. doi:10.1353/dem.2006.0001.

Andreß, H.-J., B. Borgloh, M. Bröckel, M. Giesselmann, and D. Hummelsheim (2006), 'The economic consequences of partnership dissolution: A comparative analysis of panel studies from Belgium, Germany, Great Britain, Italy, and Sweden', European Sociological Review, 22 (5), 533-60. doi:10 $.1093 / \mathrm{esr} / \mathrm{jc1} 012$.

Becker, G.S. (1981), A Treatise on the Family, Cambridge, MA: Harvard University Press.

Becker, G.S., E.M. Landes, and R.T. Michael (1977), 'An economic analysis of marital instability', Journal of Political Economy, 85 (6), 1141-87. doi:10.1086/260631.

Bernardi, F. and D. Boertien (2017), 'Non-intact families and diverging educational destinies: A decomposition analysis for Germany, Italy, the United Kingdom and the United States', Social Science Research, 63, 181-91. doi:10.1016/j.ssresearch.2016.09.004.

Bernardi, F. and J. Radl (2014), 'The long-term consequences of parental divorce for children's educational attainment', Demographic Research, 30, 1653-80. doi:10.4054/DemRes.2014.30.61.

Björklund, A., D.K. Ginther, and M. Sundström (2006), 'Family structure and child outcomes in the USA and Sweden', Journal of Population Economics, 20 (1), 183-201. doi:10.1007/s00148-006-0094-7.

Boertien, D. and J. Härkönen (2018), 'Why does women's education stabilize marriages? The role of marital attraction and barriers to divorce', Demographic Research, 38, 1241-76. doi:10.4054/DemRes .2018.38.41. 
Boertien, D. and D. Mortelmans (2017), 'Does the relationship between personality and divorce change over time? A cross-country comparison of marriage cohorts', Acta Sociologica, 61 (3), 300-16. doi: $10.1177 / 0001699317709048$.

Bradbury, T.N., F.D. Fincham, and S.R.H. Beach (2000), 'Research on the nature and determinants of marital satisfaction: A decade in review', Journal of Marriage and Family, 62 (4), 964-80. doi:10 $.1111 / \mathrm{j} .1741-3737.2000 .00964 . x$.

Charles, K.K. and M. Stephens (2001), 'Job displacement, disability, and divorce', Journal of Labor Economics, 22 (2), 489-522. doi:10.3386/w8578.

Cherlin, A.J. (2004), 'The deinstitutionalization of American marriage', Journal of Marriage and Family, 66 (4), 848-61. doi:10.1111/j.0022-2445.2004.00058.x.

Claessens, E. and D. Mortelmans (2018), 'Challenges for child support schemes: Accounting for shared care and complex families', Journal of European Social Policy, 28 (3), 211-23. doi:10.1177/ 0958928717753592.

Clayton, R.B. (2014), 'The third wheel: The impact of Twitter use on relationship infidelity and divorce', Cyberpsychology, Behavior, and Social Networking, 17 (7), 425-30. doi:10.1089/cyber.2013.0570.

Cohen, P.N. (2018), 'The coming divorce decline', Socius: Sociological Research for a Dynamic World, 5, 1-6. doi:10.31235/osf.io/h2sk6.

Coleman, M., L. Ganong, and M.A. Fine (2000), 'Reinvestigating remarriage: Another decade of progress', Journal of Marriage and Family, 62 (4), 1288-307. doi:10.1111/j.1741-3737.2000.01288.x.

Connidis, I.A., K. Borell, and S.G. Karlsson (2017), 'Ambivalence and living apart together in later life: A critical research proposal', Journal of Marriage and Family, 79 (5), 1404-18. doi:10.1111/jomf .12417 .

Cooke, L.P., J. Erola, M. Evertsson, M. Gahler, J. Harkonen, B. Hewitt, M. Jalovaara, M.Y. Kan, T.H. Lyngstad, L. Mencarini, J.-F. Mignot, D. Mortelmans, A.-R. Poortman, C. Schmitt, and H. Trappe (2013), 'Labor and love: Wives' employment and divorce risk in its socio-political context, Social Politics, 20 (4), 482-509. doi:10.1093/sp/jxt016.

Coontz, S. (2006), Marriage, a History: How Love Conquered Marriage, London: Penguin.

Coontz, S. (2007), 'The origins of modern divorce', Family Process, 46 (1), 7-16. doi:10.1111/j .1545-5300.2006.00188.x.

D’Onofrio, B.M., E. Turkheimer, R.E. Emery, K.P. Harden, W.S. Slutske, A.C. Heath, P.A.F. Madden, and N.G. Martin (2007), 'A genetically informed study of the intergenerational transmission of marital instability', Journal of Marriage and Family, 69 (3), 793-809. doi:10.1111/j.1741-3737.2007.00406.x.

de Bruijn, S., A.-R. Poortman, and T. van der Lippe (2018), 'Do parenting plans work? The effect of parenting plans on procedural,family and child outcomes', International Journal of Law, Policy and the Family, 32 (3), 394-411. doi:10.1093/lawfam/eby012.

de Vaus, D.A., M. Gray, L. Qu, and D. Stanton (2017), 'The economic consequences of divorce in six OECD countries', Australian Journal of Social Issues, 52 (2), 180-99. doi:10.1002/ajs4.13.

Dewilde, C. (2006), 'Becoming poor in Belgium and Britain: The impact of demographic and labour market events', Sociological Research Online, 11 (1). doi:10.5153/sro.1206.

Dierckx, M., D. Mortelmans, and J. Motmans (2018), 'Role ambiguity and role conflict among partners of trans people', Journal of Family Issues, 40 (1), 85-110. doi:10.1177/0192513×18800362.

DiPrete, T.A. and P.A. McManus (2000), 'Family change, employment transitions, and the welfare state: Household income dynamics in the United States and Germany', American Sociological Review, 65 (3), 343-70.

Emery, R.E. (ed.) (2013), Cultural Sociology of Divorce: An Encyclopedia, Thousand Oaks, CA: Sage.

Erola, J. and M. Jalovaara (2016), 'The replaceable: The inheritance of paternal and maternal socioeconomic statuses in non-standard families', Social Forces, 95 (3), 971-95. doi:10.1093/sf/sow089.

Eurostat (2019), Marriages and divorces (demo_nup), accessed 12 July 2019 at https://ec.europa.eu/ eurostat/cache/metadata/en/demo_nup_esms.htm.

Goldstein, J.R. (1999), 'The leveling of divorce in the United States', Demography, 36 (3), 409-14. doi: $10.2307 / 2648063$.

González, L. and T.K. Viitanen (2009), 'The effect of divorce laws on divorce rates in Europe', European Economic Review, 53 (2), 127-38. doi:10.1016/j.euroecorev.2008.05.005. 
Guzzo, K.B. (2014), 'Trends in cohabitation outcomes: Compositional changes and engagement among never-married young adults', Journal of Marriage and Family, 76 (4), 826-42. doi:10.1111/jomf .12123 .

Härkönen, J. and J. Dronkers (2006), 'Stability and change in the educational gradient of divorce: A comparison of seventeen countries', European Sociological Review, 22 (5), 501-17. doi:10.1093/ esr/jcl011.

Hauser, R., R.V. Burkhauser, K.A. Couch, and G. Bayaz-Ozturk (2016), 'Wife or frau, women still do worse: A comparison of men and women in the United States and Germany after union dissolutions in the 1990s and 2000s', Working papers, 2016/39.

Jalovaara, M. (2001), 'Socio-economic status and divorce in first marriages in Finland 1991-93', Population Studies, 55, 119-33. doi:10.1080/00324720127685.

Jansen, M., D. Mortelmans, and L. Snoeckx (2009), 'Repartnering and (re)employment: Strategies to cope with the economic consequences of partnership dissolution', Journal of Marriage and Family, 71 (5), 1271-93. doi:10.1111/j.1741-3737.2009.00668.x.

Kalmijn, M. (2007), 'Explaining cross-national differences in marriage, cohabitation, and divorce in Europe, 1990-2000', Population Studies, 61 (3), 243-63. doi:10.1080/00324720701571806.

Kaufman, G. (2000), 'Do gender role attitudes matter? Family formation and dissolution among traditional and egalitarian men and women', Journal of Family Issues, 21 (1), 128-44. doi:10.1177/ 019251300021001006.

Kelly, J.B. and R.E. Emery (2003), 'Children's adjustment following divorce: Risk and resilience perspectives', Family Relations, 52 (4), 352-62. doi:10.1111/j.1741-3729.2003.00352.x.

Lehrer, E.L. and C.U. Chiswick (1993), 'Religion as a determinant of marital stability', Demography, 30 (3), 385-404. doi:10.2307/2061647.

Lesthaeghe, R. (2010), 'The unfolding story of the second demographic transition', Population and Development Review, 36 (2), 211-51. doi:10.1111/j.1728-4457.2010.00328.x.

Levinger, G. (1965), 'Marital cohesiveness and dissolution: An integrative review', Journal of Marriage and the Family, 27 (1), 19-28. doi:10.2307/349801.

Levinger, G. (1976), 'A social psychological perspective on marital dissolution', Journal of Social Issues, 32 (1), 21-47. doi:10.1111/j.1540-4560.1976.tb02478.x.

Liefbroer, A. and E. Dourleijn (2006), 'Unmarried cohabitation and union stability: Testing the role of diffusion using data from 16 European countries', Demography, 43 (2), 203-21. doi:10.1353/dem .2006.0018.

Lundberg, S. (2012), 'Personality and marital surplus', IZA Journal of Labor Economics, 1 (1), 1-21. doi:10.1186/2193-8997-1-3.

Lyngstad, T. and M. Jalovaara (2010), 'A review of the antecedents of union dissolution', Demographic Research, 23 (10), 257-92. doi:10.4054/DemRes.2010.23.10.

Matysiak, A., M. Styrc, and D. Vignoli (2014), 'The educational gradient in marital disruption: A meta-analysis of European research findings', Population Studies, 68 (2), 197-215. doi:10.1080/ 00324728.2013.856459.

McLanahan, S. (2004), 'Diverging destinies: How children are faring under the second demographic transition', Demography, 41 (4), 607-27. doi:10.1353/dem.2004.0033.

Mortelmans, D., K. Matthijs, E. Alofs, and B. Segaert (eds) (2016), Changing Family Dynamics and Demographic Evolution: The Family Kaleidoscope, Cheltenham, UK and Northampton, MA, USA: Edward Elgar Publishing.

National Center for Health Statistics (2019), Vital Statistics of the United States, accessed 12 July 2019 at www.cdc.gov/nchs/products/vsus.htm.

Nielsen, L. (2018), 'Joint versus sole physical custody: Outcomes for children independent of family income or parental conflict', Journal of Child Custody, 15 (1), 35-54. doi:10.1080/15379418.2017 .1422414 .

Oppenheimer, V.K. (1997), 'Women's employment and the gain to marriage: The specialization and trading model', Annual Review of Sociology, 23, 431-53. doi:10.1146/annurev.soc.23.1.431.

Ozawo, M. and H. Yoon (2002), 'The economic benefit of remarriage: Gender and income class', Journal of Divorce and Remarriage, 36, 21-39. doi:10.1300/J087v36n03_02.

Roberts, B.W., N.R. Kuncel, R. Shiner, A. Caspi, and L.R. Goldberg (2007), 'The power of personality: The comparative validity of personality traits, socioeconomic status, and cognitive ability for predict- 
ing important life outcome', Perspectives on Psychological Science, 2 (4), 313-45. https://doi.org/10 $.1111 /$ j.1745-6916.2007.00047.x.

Rosenfeld, M.J. and K. Roesler (2019), 'Cohabitation experience and cohabitation's association with marital dissolution', Journal of Marriage and Family, 81 (1), 42-58. doi:10.1111/jomf.12530.

Senaeve, P. (2000), 'Echtscheiding op grond van 2 jaar feitelijke scheiding. Commentaar bij de Wet van 16 april 2000', Echtscheidingsjournaal, 5 (1), 70-8.

Sigle, W. (2016), 'Why demography needs (new) theories', in D. Mortelmans, K. Matthijs, E. Alofs, and B. Segaert (eds), Changing Family Dynamics and Demographic Evolution: The Family Kaleidoscope, Cheltenham, UK and Northampton, MA, USA: Edward Elgar Publishing, pp. 271-333.

Sigle-Rushton, W., T.H. Lyngstad, P.L. Andersen, and Ø. Kravdal (2014), 'Proceed with caution? Parents' union dissolution and children's educational achievement', Journal of Marriage and Family, 76 (1), 161-74. doi:10.1111/jomf.12075.

Solaz, A., M. Jalovaara, M. Kreyenfeld, S. Meggiolaro, D. Mortelmans, and I. Pasteels (2020), 'Unemployment and separation: Evidence from five European countries', Journal of Family Research, 32 (1), 161-74. doi:10.20377/jfr-368.

South, S.J. (1991), 'Sociodemographic differentials in mate selection preferences', Journal of Marriage and the Family, $\mathbf{5 3}$ (4), 928-40. doi:10.2307/352998.

South, S.J. (1995), 'Do you need to shop around?', Journal of Family Issues, 16 (4), 432-49. doi:10 $.1177 / 019251395016004002$.

Steele, F., H. Joshi, C. Kallis, and H. Goldstein (2006), 'Changing compatibility of cohabitation and childbearing between young British women born in 1958 and 1970', Population Studies, 60 (2), 137-52. doi:10.1080/00324720600598009.

Steinbach, A. (2019), 'Children's and parents' well-being in joint physical custody: A literature review', Family Process, 58 (2), 353-69. doi:10.1111/famp.12372.

Teachman, J.D. (2002), 'Stability across cohorts in divorce risk factors', Demography, 39 (2), 331-51. doi:10.1353/dem.2002.0019.

Trevino, M.B. (2013), 'Origins of divorce', in R.E. Emery (ed.), Cultural Sociology of Divorce: An Encyclopedia, Thousand Oaks, CA: Sage, pp. 918-21.

Veblen, T. (1965), The Theory of the Leisure Class, New York: Sentry Press.

Wagner, M. (2019), 'On increasing divorce risks', in D. Mortelmans (ed.), Divorce in Europe: New Insights in Trends, Causes and Consequences of Relation Break-Ups, Basel: Springer International Publishing.

Waite, L.J. and L.A. Lillard (1991), 'Children and marital disruption', American Journal of Sociology, 96 (4), 930-53. doi:10.1086/229613.

Wallerstein, J. (1991), 'The long-term effects of divorce on children: A review', Journal of the American Academy of Child and Adolescent Psychiatry, 30 (3), 349-60. doi:10.1097/ 00004583-199105000-00001.

Wolfers, J. (2006), 'Did unilateral divorce laws raise divorce rates? A reconciliation and new results', American Economic Review, 96 (5), 1802-20. doi:10.1257/aer.96.5.1802.

$\mathrm{Wu}, \mathrm{Z}$. (1995), 'The stability of cohabitation relationships: The role of children', Journal of Marriage and the Family, 57 (1), 231-6. doi:10.2307/353831. 